\title{
COVETING THY NEIGHBOR'S \\ MANUFACTURING: THE DILEMMA \\ OF STATE INCOME APPORTIONMENT
}

\author{
Austan Goolsbee \\ Edward L. Maydew
}

\author{
Working Paper 6614 \\ http://www.nber.org/papers/w6614

\section{NATIONAL BUREAU OF ECONOMIC RESEARCH \\ 1050 Massachusetts Avenue \\ Cambridge, MA 02138 \\ June 1998}

We would like to thank Merle Erickson, Steve Levitt, Lillian Mills, Richard Sansing, Doug Shackelford, Joel Slemrod, and seminar participants at the 1998 University of North Carolina Tax Conference for helpful comments, and to thank the Price Waterhouse Foundation, the American Bar Foundation, the Illinois Manufacturers Association, and the University of Chicago, Graduate School of Business for financial support. Any opinions expressed are those of the author and not those of the National Bureau of Economic Research.

(C) 1998 by Austan Goolsbee and Edward L. Maydew. All rights reserved. Short sections of text, not to exceed two paragraphs, may be quoted without explicit permission provided that full credit, including (C) notice, is given to the source. 
Coveting Thy Neighbor's Manufacturing:

The Dilemma of State Income Apportionment

Austan Goolsbee and Edward L. Maydew

NBER Working Paper No. 6614

June 1998

\section{ABSTRACT}

This paper investigates the economic impact of the apportionment formulae used to divide corporate income taxes among the states. Most apportionment formulae, by including payroll, turn the state corporate income tax at least partially into a payroll tax. Using panel data from 1978 1994, the results show that this distortion has an important effect on state-level employment. For the average state, reducing the payroll weight from one-third to one-quarter increases manufacturing employment around $3 \%$ and the result is highly robust. The results also indicate that apportionment changes have important negative externalities on other states in that the effects of the apportionment formula on aggregate employment is zero. Every job gained within a state from an apportionment change is taken from another state. This externality suggests that the U.S. would be better off if the apportionment formula were set at a federal level. The paper also shows that because the payroll component of the tax is administered on top of the existing payroll tax, the deadweight loss from this component of state corporate income taxation may be significant, despite the low tax rates.

\author{
Austan Goolsbee \\ Graduate School of Business \\ University of Chicago \\ 1101 E. 58th Street \\ Chicago, IL 60637 \\ and NBER \\ goolsbee@gsb.uchicago.edu
}

\author{
Edward L. Maydew \\ Graduate School of Business \\ University of Chicago \\ 1101 E. 58th Street \\ Chicago, IL 60637
}




\section{Introduction}

Faced with the continuing devolution of resources and responsibilities from the federal government back to the states and the decline of manufacturing employment throughout the country, state governments have repeatedly changed their tax systems in the last 20 years to encourage employment and investment. Enterprise zones, tax concessions and corporate rate cuts have been common and have also been the subject of extensive academic research.' Work using general measures like the average corporate tax burden in a state or the statutory corporate tax rate coupled with aggregate data has often found negligible effects of tax policy. More recent studies looking at micro-level investment decisions or at more specific tax incentives such as Bartik (1985), Papke (1991), or Hines (1996) have found much larger effects.

An important feature of state taxation that has been relatively neglected in empirical work is the state income apportionment formula by which companies allocate their national income across state tax jurisdictions. ${ }^{2}$ This formula usually attributes income based on a firm's geographic distribution of payroll, property, and sales. McLure (1980) first demonstrated that formulary apportionment largely transforms the state corporate income tax into three separate taxes on the factors in the apportionment formula. Since payroll is usually one of the factors, the formula could have important effects on employment.

State legislatures and their constituents seem to understand this and have actively attempted to modify their states' apportionment formulae to stimulate employment and investment. The theoretical work of Gordon and Wilson (1986) and later Anand and Sansing (1997), however,

\footnotetext{
'For a discussion of the literature see Carroll and Waslynko (1990).
} 
indicates that the tax choices of individual states will have negative externalities on their neighbors and this put states into a prisoner's type dilemma where they may end up with a series of beggarthy-neighbor policies.

The impact of state tax policy on economic performance and the externalities of tax policy on other states are central to public finance and the apportionment formula provides an excellent place to examine such issues. In addition, the rising interest in inter-jurisdictional tax issues and the recent proposals to convert the taxation of multinational companies to a cross-country formula apportionment system similar to the system used within the United States have generated considerable interest among policy makers in the economic effects of factor apportionment. ${ }^{3}$

In this paper, we use detailed panel data for the U.S. states from 1978-1994 and control for a variety of non-tax factors to examine the relationship between employment and state apportionment formulae. In doing so, our results establish three important facts about these state tax policies.

First, we provide the first robust evidence that the apportionment formula has a large and significant real effect on a state's economy. The payroll weight is a significant determinant of state employment. We find that for the average state, reducing the payroll weight from one-third to onequarter increases manufacturing employment by approximately $3 \%$ and that this is robust to the choice of the tax rate and the inclusion of year dummies and other controls. Further, we show that these significant employment effects imply that although increasing the sales weight in a state may lead to corporate income tax revenue losses (see Pomp, 1987), the increased employment generates

\footnotetext{
${ }^{2}$ Exceptions include the empirical work of Weiner (1996a), and Klassen and Shackelford (1997).
} 
an indirect source of additional personal income tax revenue. The results suggest that this additional revenue reduces and may even exceed the corporate revenue loss for some recently proposed formula changes.

Second, we are able to explore the externalities that one state's apportionment formula has on other states. We show the startling conclusion that while the within state employment effect of changing the apportionment formula is large, the aggregate effect is literally zero. Employment does increase in states that cut their payroll weights but every job comes directly from another state. In this way our results show how difficult it is to maintain harmony in the formulae across states, a fact fully consistent with theoretical predictions and with the ongoing trends in apportionment decisions. The large externality suggests that the U.S. as a whole would be better off moving away from a decentralized system to a federally determined apportionment formula along the lines of Canada.

Third, our results show that although the effective state corporate tax rate on payroll is very low (approximately 1\%), it can create a substantial deadweight loss because the tax is administered on top of the existing $15 \%$ payroll tax and the cross-state employment response is large. Our calculations suggest that the deadweight loss from instituting a corporate income tax at the mean rate and with a standard, equally weighted apportionment formula is as much as $15 \%$ the revenue generated.

The paper proceeds in six parts. Section 2 presents a simple theoretical model of how income apportionment affects the employment decisions of firms and describes the existing

\footnotetext{
${ }^{3}$ For discussions of these proposals see Shackelford and Slemrod (1998), Wetzler (1995), or Weiner (1996b).
} 
literature in the area. Section 3 discusses the panel data and the empirical specification. Section 4 presents the results and shows them to be robust. Section 5 discusses the revenue implications, measures the externality, and calculates the deadweight loss. Section 6 concludes.

\section{The Theory and Literature of Formula Apportionment}

Each state taxes corporate income at its own rate but corporations often do business in more than one state. The states, therefore, must decide how to apportion income between the firm's states of operation in order to avoid multiple taxation of the same income. Their solution has been to use an apportionment formula. The most common formula is to apportion firm income using three factors: property, payroll, and sales. If a firm's overall profit is $\pi$, then the profit attributed for tax purposes to state $j, \pi_{j}$, is

$$
\pi_{j}=\left(\alpha_{i}^{P} \frac{P_{i}}{P}+\alpha_{j}^{L} \frac{L_{i}}{L}+\alpha_{j}^{S} \frac{S_{i}}{S}\right) \pi
$$

where $\mathrm{P}$ is total property, $\mathrm{L}$ is the total payroll and $\mathrm{S}$ is total sales while $\mathrm{P}_{\mathrm{j}}$ and $\mathrm{L}_{\mathrm{j}}$ and $\mathrm{S}_{\mathrm{j}}$ are

property, payroll and sales in state $\mathrm{j}$ and $\alpha_{j}^{f}$ is the weight in the apportionment formula for factor $\mathrm{f}$ in state j. The most common formula has been a one-third weight on each factor (also known as the equal-weighted sales formula).

McClure (1980) has shown that using this apportionment formula largely transforms the corporate income tax into a direct tax on the factors in the formula. To see why note that the 
overall corporate tax rate in an individual state with formula apportionment and a statutory marginal tax rate $\mathrm{t}_{\mathrm{j}}$ is

$$
\tau_{j}=\left(\alpha_{j}^{P} \frac{P_{j}}{P}+\alpha_{j}^{L} \frac{L_{j}}{L}+\alpha_{j}^{s} \frac{S_{j}}{S}\right) t_{j}
$$

and the firm's overall marginal tax rate, $\tau$, is simply the sum of the $\tau_{j}$ over all its states of operation:

$$
\tau=\sum_{j} t_{j} \alpha_{j}^{P}\left(\frac{P_{j}}{P}\right)+\sum_{j} t_{j} \alpha_{j}^{L}\left(\frac{L_{j}}{L}\right)+\sum_{j} t_{j} \alpha_{j}^{S}\left(\frac{S_{j}}{S}\right)
$$

Formula (3) makes clear that if a firm alters the location of its workers even with no change in its profitability, this will have a direct effect on its marginal tax rate. In the simplest example, if a firm changes payroll in state $\mathrm{j}$ by shifting payroll from other states but leaving its total payroll unchanged (i.e., $\partial L / \partial L_{j}=0$ ), the firm's overall marginal tax rate will change according to ${ }^{4}$

$$
\frac{\partial \tau}{\partial L_{j}}=\left(\frac{1}{L}\right)\left(t_{j} \alpha_{j}^{L}-\sum_{i \neq j} t_{i} \alpha_{i}^{L} \frac{L_{i}}{\sum_{i \neq j} L_{i}}\right) .
$$

This equation shows that changing employment at the margin raises the firm's marginal tax rate by an amount that depends positively on state j's payroll tax burden and negatively on the weighted average of the other states' payroll tax burdens.

Depending on how much firms respond to marginal tax rates, states may be able to reduce their payroll weight, increase their sales weight, and thereby reduce the tax burden on employment 
in their state by partially exporting the tax to out-of-state companies. Policy makers understand this aspect of the tax exporting issue and as a result, have repeatedly changed state apportionment formulae to increase the sales weight. ${ }^{5}$ Gordon and Wilson (1986) and Anand and Sansing (1997) have shown that such apportionment maneuvers have negative externalities on other states. The nation would be better off if everyone could cooperate when setting their formulae, but that this is not a sustainable equilibrium. In practice, we will show what an accurate this characterization is.

Although theoretical work such as McLure (1980), Gordon and Wilson (1986), and Anand and Sansing (1997) has indicated that the apportionment formula should affect economic decisions, existing empirical work has not concurred. Weiner (1994) finds no evidence that apportionment affected investment cross-sectionally in 1977. Weiner (1996a) presents cross-sectional evidence that formula apportionment has no independent effect on capital labor ratios and that, looking at the change from 1982 to 1990 , apportionment formula changes have only a modest and borderline statistically significant influence on capital spending. Klassen and Shackelford (1997) do find evidence that the formula matters for the location of sales, but not for decisions about the real factors (employment and property).

We believe that one of the primary reasons that the evidence in these papers has not found a more important role for the apportionment formula is that they have not been able to fully control for unobservables because they used only cross-sectional or very limited panel data. By moving to

\footnotetext{
this assumes, for simplicity, that the shift from each state is proportional to it current share of payroll.

${ }^{5}$ Actually, Gordon and Wilson (1986) show that the apportionment formulae can have much more complex effects, as well. Depending on the form of apportionment, there may be incentives for mergers across states, for "crosshauling" of output. or for companies selling more than one good to locate all their production in a single state. They atso show that these distortions could be eliminated by abolishing the corporate income tax and replacing it with direct taxes on the factors.
} 
richer data, our results are able to bring the empirical results in line with the theoretical findings and to highlight the importance of state level decisions. Our primary objective is to estimate the extent to which changes in a state's apportionment formula affect employment in that and other states.

\section{Methodology and Data}

Our study compiles a panel data set on the apportionment formulae and corporate tax rates for states from 1978-1994. There have been approximately 20 different state apportionment formula changes over this period and this variation allows us to develop reasonably precise estimates of their economic effects. Because of the long time period, we are also able to control for economic factors that independently influence employment.

The scope of our study is limited in that we focus mainly on the manufacturing sector. We do so primarily because that is where apportionment issues are most likely to be important and it has also been the primary area of academic study and policy making. Other sectors such as banking or insurance have special apportionment issues.

The data used in our study are as follows. First the time series on the apportionment formulae cover all states with a corporate income tax. These data are gathered from Commerce Clearing House's State Tax Handbook, various state tax codes, issues of Significant Features of Fiscal Federalism and discussions with the state departments of revenue in Ohio and Illinois.

Figure 1 shows the number of states that have adopted more than the standard $1 / 3$ weight on sales in their apportionment formulas over this sample, not counting states with optional apportionment formulae. There is a consistent upward trend that begins after 1978 with the 
Moorman case in which the Supreme Court ruled that Iowa's use of the single factor sales apportionment formula was constitutional. Once the constitutionality of increased weight on the sales factor had been established, it was only a matter of time until states began trying to export their corporate income tax burdens onto businesses in other states.

We match these apportionment formulae with state employment and earnings data compiled by the Bureau of Economic Analysis. These data include total private employment and total manufacturing employment by year for each state and are compiled from the ES-202 series of the Bureau of Labor Statistics and reported in the B.E.A.'s State Personal Income database. We also include the growth rate of average state personal income from the same source. For the national economy, we use data on the unemployment rate and the log of national employment. We allow the coefficient on the latter to vary by state in an attempt to control for population changes in a way that is not endogenous. The descriptive statistics for all the data in our sample are listed in table 1.

Using these data, our basic empirical specification will regress the log of employment in state $\mathrm{j}$ in year $\mathrm{t}$ as follows:

$$
\ln \left(E M P L_{j t}\right)=\alpha_{i}+\beta_{1}\left(\operatorname{Tax}_{j t}\right)+\beta_{1}\left(\overline{\operatorname{Tax}_{t}}\right)+\Gamma_{1}^{\prime} Z_{i}+\Gamma_{2}^{\prime} X_{j t}+\varepsilon_{j}
$$

where $\mathrm{TAX}_{\mathrm{jt}}$ includes measures of the apportionment induced tax burden on payroll in the state, $\overline{T a x_{1}}$ is the weighted average tax burden on payroll for all states in that year, the $\mathrm{Z}_{1}$ are annual controls to account for macroeconomic factors that independently influence state employment (e.g., the national unemployment rate) or year dummies which absorb common macro variation, and the $\mathrm{X}_{\mathrm{jt}}$ are state level controls as well as state specific time trends. 
The basic approach is to estimate whether, conditional on the state of the economy and other variables, employment is higher when a state puts less weight on the payroll factor in its apportionment formula. The results below support the proposition.

\section{Results}

\subsection{Main Results.}

Column (1) of Table 2 presents a basic panel regression for the log of manufacturing employment in a state on the tax terms, state fixed effects, state time trends, the state personal income growth rate, the national unemployment rate, and the log of national employment interacted with the state dummies to account for growth in the labor force. Following the theory presented above, our tax terms are the state corporate tax rate interacted with the payroll weight in the apportionment formula and the weighted average of the same variable for all states in that year (states are weighted by average manufacturing employment over the sample).

In this basic specification, the coefficients are significant and have the predicted signs. The non-tax variables are unsurprising and the tax variables are statistically significant. Reducing the tax burden on payroll in the state by reducing the corporate rate or the payroll weight in the apportionment formula increases manufacturing employment significantly. When other states reduce their payroll tax burden it does the opposite. The magnitude of the own-tax coefficient indicates that for a state with the mean corporate tax rate, changing from a one-third to a onequarter payroll weight (also known as a "double-weighted sales" formula) increases manufacturing employment by $1.2 \%$. 
In column (2) we take federal corporate taxation into account, assuming that all states' corporate income taxes are deductible from the federal tax, for simplicity. We do this by replacing the state tax rate with the state rate times one minus the federal rate. Here again the evidence supports the view that higher payroll tax burdens within a state reduce employment and vice versa for the payroll tax burden in other states. The magnitudes are also very similar. Moving from onethird to one-quarter weighting on payroll increases employment (at the mean state and federal tax rates) by $0.8 \%$.

While these specifications seem to indicate that the apportionment formula is important, both specifications impose that the apportionment formula and the corporate tax rate have identical effects. The apparent effect of apportionment changes, however, might be caused by spurious correlation with some other variable. Firms may respond only to the corporate rate, for example, and by including only an interaction term this makes the payroll weight look significant. On the other hand, if the true marginal tax rate facing the firm differs from the statutory rate, this will tend to reduce the estimated effect of the apportionment formula in the interaction term.

Columns (3) and (4), therefore, repeat the specifications of (1) and (2), but break the income tax induced payroll burden into two components: the payroll weight and the corporate tax rate. In both specifications, the corporate tax rate does not reduce the importance of the payroll weight. Indeed, in both cases the coefficient on the tax rate is not significantly different from zero while the coefficient on the payroll weight is both significant and the estimated effect is quite large. ${ }^{6}$ Moving from one-third to one-quarter payroll weight increases manufacturing by $3.1 \%$ in column (3) and

\footnotetext{
${ }^{6}$ The results were almost identical when we calculated the marginal effects of the tax rate and the payroll weight
} 
$2.7 \%$ in column (4) and in both cases when other states reduce their payroll tax burdens, this reduces employment in state $\mathrm{j}$.

Thus there probably is error in the true tax rate facing firms which reduces the coefficient on taxes and by separating the two components we can isolate the effect of the formula directly. In all four regressions, the state tax rate has no significant impact and the payroll weight does. Because this pattern was repeated in all the specifications we will present, the results that follow will look only at the payroll weight. Columns (5) and (6) simply verify that excluding state tax rates does not change the estimates on the payroll weight.

\subsection{Advanced Results: Endogeneity and Controls}

Since table 2 indicates that there are large effects of apportionment formula decisions, we want to establish that these effects are not just spuriously correlated by endogenous tax policy or by within state employment shifts between sectors.

If policy makers change the apportionment formula based on their state's economic performance, this will bias the coefficients but we doubt that this mechanism has generated the results presented here for three reasons. First, we controlled for state income growth in the regressions. Second, even if there is endogeneity, we normally envision tax stimuli as being counter-cyclical, i.e., policy makers reducing the payroll weight to encourage employment when it is at its lowest. This should bias the results downward. Finally, in a previous version of this paper (Goolsbee and Maydew, 1997) we estimated a policy regression attempting to explain when states 
change their apportionment formulae and the state economic conditions were not significant explanatory variables.

Another way control for many unobservable factors is to note that there is both time-series and cross-sectional variation in the apportionment formulae and to include year dummies to absorb the effects of economy wide shocks. We estimate this regression in table 3 , column (1). The national unemployment rate and the effect of average tax rates in a given year are now absorbed in the year dummies but the effect of the apportionment formula within the state is still identified. In this equation, the year dummies are very significant, indicating that significant macro shocks affecting all states do exist. The impact of the apportionment formula, however, has the exactly same pattern as it had in table 1. Higher payroll weights significantly reduce manufacturing employment. Here, moving from equal to double weighted sales increases a states manufacturing employment by $2.7 \%$.

The impact of the apportionment formula is robust to choices of specifications and the inclusion of year dummies. It is possible, of course, that whenever a state adopts a lower payroll weight, it is only indicative of a "pro-business" outlook on the part of the government and is correlated with other, simultaneous but unobservable policy changes which are, in fact, the source of the estimated employment effects. It is obviously quite difficult to counter such an argument but we find the view implausible since the one measure we do have of the business orientation of a state, namely the state corporate tax rate shows no such correlation. In the data, the payroll weight and the state corporate tax rate have a modest negative correlation and changes in the two series have zero correlation. 


\subsection{Advanced Results: Job Shifting and Downgrading}

Next, we document that the increases in manufacturing employment in states lowering their payroll weights do not result from simple shifts of workers into manufacturing from nonmanufacturing jobs in the same state. Column (2) repeats the specification of column (1) with the complete controls and year dummies but for the log of total employment rather than just manufacturing employment. The coefficients are again significant and large and are quite similar in magnitude to the results for manufacturing. Moving from equal to double-weighted sales raises total employment by $2.1 \%$. Since manufacturing averages about $20 \%$ of employment, such results imply that employment in non-manufacturing sectors must also rise. A shift would appear as a zero coefficient on total employment.

Column (3) repeats the same regression but for the log of the ratio of employment to state population and the coefficient is significant and of similar magnitude. This suggests that the employment increases come from existing unemployed or out of the labor force workers within the state, as opposed to the migration of workers from other states (which also increases population). ${ }^{7}$

Column (4) shows that the jobs created from the change in the payroll weight do not seem to pay lower wages than the average job, either. It regresses the log of the average real wage in manufacturing on the controls and the year dummies but the results indicate that the apportionment

\footnotetext{
${ }^{7}$ Interacting the payroll weight with the employment to population ratio in the regression on manufacturing employment showed that the employment effects are significantly smaller when the employment rate in a state is already high. This appears to further the point but we do not report the regression here for the sake of brevity.
} 
formula has no significant effect. The point estimate is very small, as well, indicating that a switch to double weighted sales lowers wages by $0.3 \%$--less than $1 / 20$ th of a standard deviation. ${ }^{8}$

\subsection{Advanced Results: Long-Run Effects}

Finally we explore whether the effects of apportionment reform are larger in the long-run. It is likely that it takes time for firms to fully adjust to tax changes and that they are more elastic to differences in tax systems across states in the longer-run than they are immediately. The results in column (5) which include the controls and the year dummies but also include lags of the payroll weight illustrate this pattern. All the coefficients are negative indicating that the effect gets larger over time and although the individual coefficients are measured imprecisely due to collinearity, the sum of the coefficients after several years is estimated very precisely. Here, reducing the payroll factor from one-third to one-quarter increases manufacturing employment by less than $1 \%$ after a lag of one year but up to $3.6 \%$ after several years.

Here we can also address the issue of whether the employment effects are estimated differently if we use differenced data rather than levels regressions with fixed effects. The previous result in levels showed that the employment effects in the very short-run may be small which will tend to lead a simple first-differenced regression to find little effect. Once we allow for lagged effects, however, identification becomes easier. Column (6) estimates this differenced regression for states which experience a change in the payroll weight at least once in the sample. Although the coefficients are estimated somewhat imprecisely, the sum is significant at the $10 \%$ level and not

\footnotetext{
${ }^{8}$ Given this result, it is not surprising that in regressions using total payroll rather than employment, we obtained nearly identical results so we do not report them.
} 
statistically different from the sum in column (5). ${ }^{9}$ The point estimate indicates that moving to double-weighted sales increases employment by $2.2 \%$ in the long-run.

\section{Revenues, Externalities, and Deadweight Loss}

\subsection{Revenue Implications and the Cost per Job}

The results have shown that apportionment changes can significantly stimulate job growth. Yet when state departments of revenue calculated the consequences of apportionment reform for tax revenues, they routinely look only at the revenue losses on the corporate side. ${ }^{10}$ Our results, however, suggest that by stimulating job creation, apportionment reform generates indirect revenue from the personal income tax that may offset the corporate revenue losses.

An interesting comparison, however, is to look at the revenue cost of the proposal divided by the jobs created. This "dollars-per-job" measure is a common way to evaluate business incentives such as enterprise zones or other jobs programs. Papke (1993) cites several studies of this measure which range from about $\$ 4,500$ to as much as $\$ 60,000$ but reasonable averaging around $\$ 10,000$.

To evaluate apportionment changes, we take the costs estimated by the Departments of revenue in New Jersey and Pennsylvania in 1995 for moves to double weighted sales. New Jersey forecast a $\$ 33$ million reduction in corporate tax revenue. Pennsylvania forecast a $\$ 41$ million cost. Depending on the specification, our results predict that the change would increase manufacturing

\footnotetext{
${ }^{9}$ Including states whose apportionment formulae did not change over the sample gave a similar point estimate with a larger standard error.

${ }^{10}$ Some argue that these corporate revenue losses may be underestimated by state departments of revenue (Pomp, 1987).
} 
employment by 2.2 to $3.4 \%$. For New Jersey this is an increase of between 11,000 and 17,500 jobs for a cost of approximately $\$ 2000$ to $\$ 3000$ per job. For Pennsylvania, whose manufacturing sector is larger, the cost is between $\$ 1200$ and $\$ 2000$ per job. If we use the specification for total employment, the costs are even lower.

The results, therefore, indicate that as a means of stimulating job creation, apportionment changes are a potentially cost effective way to increase employment relative to other government programs. It is important to note, however, that part of this cost savings may arise because many government jobs programs are targeted to help those not on the margin. The costs of inducing a firm to hire a very unskilled person living in a depressed area may be much higher than inducing the firm to hire one more worker of any type.

\subsection{Externalities and the Apportionment Formula}

The results in table 2 showed a significant effect of the mean national payroll tax burden on a state's employment. We have seen that when a state lowers its payroll weight, this has a positive effect on that state's employment. At the same time, since it reduces the average tax burden on payroll, it will reduce employment in other states, albeit by a small amount. This is precisely the externality which drives budget makers into tax competition.

To demonstrate the size of the externality, we calculate the within and across state impact for a state of the mean size and with a mean corporate tax rate using specifications (5) and (6) of table 1. Mean manufacturing employment is about 417,000 for a single state and $17,970,000$ for the nation. If the mean state reduces its payroll weight from one-third to one-quarter, this increases 
within state manufacturing employment by $2.7 \%$ in equation (6) or $3.1 \%$ in equation (5)--an increase of approximately 11,200 or 12,800 jobs.

Taking into account the size of the average state, this same change of .083 in the payroll weight, will (at the mean state and federal corporate income tax) lower the average national payroll tax burden by .000136 in (5) and .000074 in (6). Using the coefficients on the mean tax burden terms in these equations, this implies a decrease in employment for every state of $.073 \%$ in (5) and $.070 \%$ in (6). These percentages may seem small but with $17,553,000$ workers in manufacturing who do not reside in the state changing its apportionment formula, these small effects add up quickly. The percentages here imply that the apportionment change reduces employment among manufacturing workers in other states by 12,400 in (6) and 12,800 in (5)--almost identical to the increase in jobs in the state changing its formula. The result is striking. On average, the 12,000 jobs created for the state making the apportionment change correspond to a loss of around 12,000 jobs from other states. The net change is not significant and, indeed, the magnitude is almost exactly zero.

This puts the dilemma of income apportionment in the clearest possible focus. Each state can have an immediate positive impact on its level of employment by cutting the payroll weight unilaterally but such an action will hurt other states. Since each state faces the same incentive, consensual agreement on an equally weighted apportionment formulae is just the prisoner's dilemma writ large.

This negative externality suggests that the apportionment formulae should be set at the federal level. Doing so could improve national welfare by preventing the beggar-thy-neighbor 
formula changing at the state level. This lesson also has extremely important implications for the ongoing discussions about converting international taxation in the U.S. to an apportionment formula style system rather than the current, multiple-books system (see Shackelford and Slemrod, 1998; Wetzler, 1995; Weiner, 1996b). If each nation can choose its apportionment formula in such a scheme, then each nation will face the same incentive to change its formula that the states face today and each nation will likely have the same negative externality on its neighbors that we see here. Such a system is not stable.

\subsection{Deadweight Loss}

Finally, we consider the deadweight loss arising from the state corporate income tax due to the apportionment feature. Our calculation will necessarily be over-simplified to make a point. A careful calculation of the DWL from state corporate income taxation would need to account for the DWL arising from the property and sales portions of the income tax as well as the general equilibrium effects arising from taxing different firms differently in the same states and, potentially, the relative rates of personal taxation, as well." These are beyond the scope of this paper. Our point here is to demonstrate that even small taxes such as the payroll tax equivalent of the state corporate income tax can generate rather sizable efficiency losses when they are on top of existing tax rates.

\footnotetext{
"See Gordon and Mackie-Mason (1994; 1997) or Goolsbee (1998) for a discussion of why the relative taxation of personal and corporate rates can generate DWL when firms can choose not to incorporate and for estimates of the DWL in such cases.
} 
To illustrate this, note that the DWL from a state level tax is approximately equal to $-\frac{1}{2} \tau^{2} \eta_{D}$, where $\tau$ is the tax rate and $\eta_{D}$ is the elasticity demand. ${ }^{12}$ The state corporate income tax might seem basically innocuous from a DWL perspective based on the size of either of these parameters. State rates are low to begin with and when multiplied by the payroll weight give tax rates between 1 and 3 percent, depending on the deductibility issue. As for the elasticity, the results above showed that the aggregate effect of the policy was negligible so the elasticity would appear to be very small, as well. Together these imply that the efficiency loss would be very close to zero.

This conclusion would be erroneous, however. First, the payroll component of the income tax is administered on top of an existing $15 \%$ payroll tax, which makes the deadweight loss much larger. Instituting a corporate income tax with the mean rate (.073) and a $1 / 3$ weight on payroll does not raise $\tau$ from, say, 0 to .024 ( 0 to .011 with federal deductibility) but instead from 0.150 to $0.171\left(.150\right.$ to .159 with federal deductibility).$^{13}$

Next, the correct elasticity for the DWL does not measure the aggregate effect of the state policies but rather the state effect of state policies. If state taxes drive workers into other states, this will create deadweight loss even if no jobs are destroyed in the aggregate. ${ }^{14}$ Our largest results suggested that instituting a corporate income tax with an equal-weighted formula would reduce employment by $14 \%$. The increase in the price from .15 to .171 is also a $14 \%$ increase so the elasticity is approximately 1.

\footnotetext{
12 This assumes that the labor supply facing the firm is perfectly elastic. Our results showed, however, that apportionment changes increased state employment but not wages and is thus consistent with the assumption.

${ }^{13}$ We are assuming that the federal payroll tax is deductible from the state corporate income tax in this calculation.

${ }^{14}$ See Anderson and Meyer (1997) for a discussion of the DWL of taxes with small aggregate but large crosssectional effects in the context of unemployment insurance.
} 
The DWL of the state corporate income tax is now the change in total DWL from moving

to the higher payroll tax. This is $D W L_{1}-D W L_{0}=-\frac{1}{2} \eta_{D}\left[\tau_{1}^{2}-\tau_{0}^{2}\right]$ and in this case it amounts to approximately $0.33 \%$ of the total payroll (the result is almost identical if federal deductibility is ignored). Since the state payroll rate itself is only $2.4 \%$ of payroll, the implied DWL is almost $15 \%$ of the revenue generated on the margin even though there is no aggregate effect of this policy.

We should note that this calculation is based on our largest estimates so the true DWL may be smaller. Nevertheless, the calculation shows that the true number is likely to be much larger than a casual glance might suggest. We also emphasize that this is not the DWL associated with changing the apportionment formula by increasing payroll weights and increasing the sales weight. To calculate the latter would require an estimate of the efficiency gain from reducing the equivalent tax on sales, a subject on which we have no data. ${ }^{15}$ This calculation is, rather, the efficiency loss from the payroll component of having a corporate income tax at all.

\section{Conclusion}

Economic theory predicts that a state corporate income tax puts a distortionary burden on the factors in the apportionment formula. As a result, changing the apportionment formula to reduce the weight on payroll should affect employment. Our results verify this with panel data on state employment from 1978-1994. The results are highly robust and suggest that switching from one-third to one-quarter payroll weight increases manufacturing employment in a state by approximately $3 \%$. This employment effect suggests that static revenue calculations taking into 
account only corporate tax revenue effects may seriously misstate the total revenue effects of such a change.

The results also show that state decisions negatively affect employment in other states. This externality creates pressure for states to act first in changing their formulae and implies that the nation would be better off setting state apportionment formulae at the federal level, such as in Canada. The aggregate effects of state apportionment changes are almost exactly zero.

Finally, we illustrate that since the payroll component of the tax is administered on top of an existing payroll tax of $15 \%$ and the within state employment effects of the tax are substantial, the deadweight loss of state corporate income taxes are non-negligible despite their low rates. Our calculations suggest that the efficiency loss from the payroll component may amount to as much as $15 \%$ of the revenue generated.

The results confirm that state tax policies can have important effects on state economies and that externalities are important. The results will encourage states to reduce their apportionment formulae in an effort to stimulate employment but the same conclusions may encourage the federal government to try to coordinate the state formulae to prevent the ongoing breakdown of cooperation which pits states against one another in a race to the bottom. The results should give serious pause to those who advocate worldwide formula apportionment for multi-national companies; the dilemma of income apportionment raised in this paper almost certainly does not end at the water's edge.

\footnotetext{
${ }^{15}$ Klassen and Shackelford (1997) show that the effect of the apportionment formula on sales may be quite large.
} 


\section{REFERENCES}

Advisory Commission on Intergovernmental Relations (various), Significant Features of Fiscal Federalism. (GPO; Washington, D.C.)

Anand, B. and R. Sansing (1997), "The Weighting Game: Formula Apportionment as an Instrument of Public Policy" Yale S.O.M. Working Paper \#45, Working Paper Series C.

Anderson, P. and B. Meyer (1997), "The Effects of Firm Specific Taxes and Government Mandates with an Application to the U.S. Unemployment Insurance Program," Journal of Public Economics 85, pp. 119-145.

Bartik, T. (1985), "Business Location Decisions in the United States: Estimates of the Effects of Unionization, Taxes, and Other Characteristics of States," Journal of Business and Economic Statistics, 3, pp. 14-22.

Carroll, R. and M. Waslynko (1990), "The Shifting Fate of Fiscal Variables and Their Effect on Economic Development" NTA-TIA Proceedings of the Eighty Second Annual Conference, pp. 283-90.

Commerce Clearing House (various), State Tax Handbook. (Chicago, Commerce Clearing House)

Goolsbee, A. (1998), "Taxes, Organizational Form, and the Deadweight Loss of the Corporate Income Tax," Journal of Public Economics

Goolsbee. A. and E. Maydew (1997), "The Economic Effects of the Income Apportionment Formula" Mimeo, University of Chicago.

Gordon, R. and J. Mackie-Mason (1994), "Tax Distortions to the Choice of Organizational Form," Journal of Public Economics, 55, pp. 279-306

Gordon, R. and J. Mackie-Mason (1997), "How Much do Taxes Discourage Incorporation?" Journal of Finance, 52, 477-505.

Gordon, R. and R. Wilson (1986), "An Examination of Multijurisdictional Corporate Income Taxation Under Formula Apportionment," Econometrica 54(6), pp. 1357-73.

Hines, J. (1996), "Altered States: Taxes and the Location of Foreign Direct Investment in America" American Economic Review, 86(5), pp. 1076-1094.

Klassen, K. and D. Shackelford (1997), "State and Provincial Corporate Tax Planning: Income, Sales, Assets, and Compensation Management," Mimeo U.N.C. 
McLure, C. (1980), "The State Corporate Income Tax: Lambs in Wolves' Clothing" from The Economics of Taxation, H. Aaron and M. Boskin, eds. (Brookings; Washington, D.C.)

Papke, L (1991), "Interstate Business Tax Differentials and New Firm Location" Journal of Public Economics, 45, pp. 47-68.

Pomp, R (1987), "Reforming a State Corporate Income Tax," Albany Law Review, 3/4, 375-788.

Shackelford, D. and J. Slemrod (1998), "The Revenue Consequences Of Using Formula Apportionment To Calculate U.S. And Foreign-Source Income: A Firm-Level Analysis," International Tax and Public Finance

Weiner, J (1994), Company Taxation for the European Community. How Sub-national Tax Variation Affects Business Investment in the United States and Canada. Ph.D. Dissertation. Harvard University.

Weiner, J. (1996a), "Estimates of How the Unitary Tax Affects Business Investment" Presented at the A.S.S.A. meetings San Francisco. O.T.A. Mimeo.

Weiner, J (1996b), "Using the Experience in the U.S. States to Evaluate Issues in Implementing Formula Apportionment at the International Level," Tax Notes International, December 23, pp. 2113-2144.

Wetzler, J. (1995), "Should the U.S. Adopt Formula Apportionment?" National Tax Journal, 48(3), pp.357-362. 


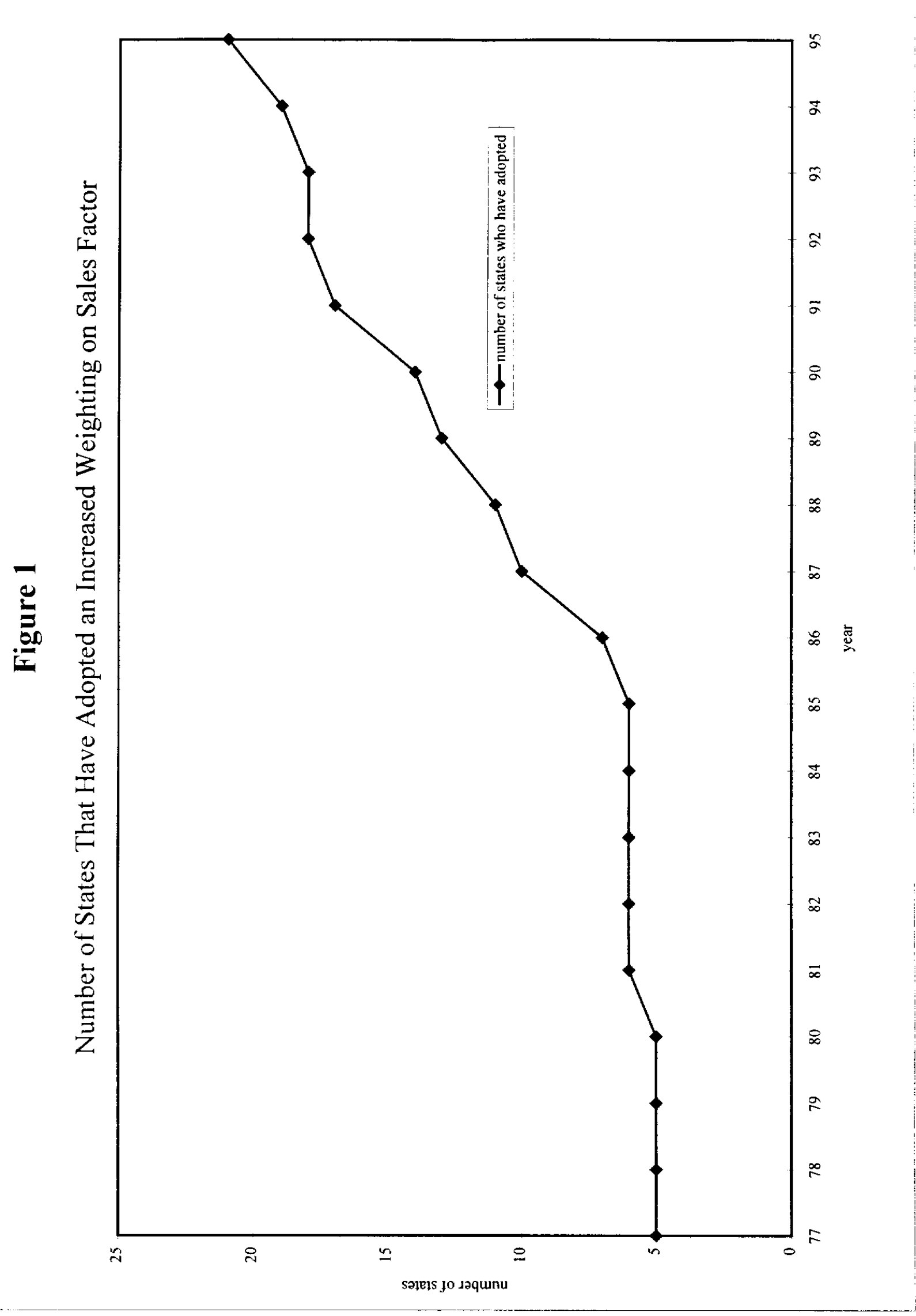




\section{Table 1}

Descriptive Statistics for State Panel from 1978-95

\begin{tabular}{lcc}
\hline \hline Variables $^{\mathrm{a}}$ & Mean & Standard deviation \\
\hline Payroll weight & 0.314 & 0.047 \\
State payroll burden & 0.013 & 0.004 \\
State corporate tax rate & 0.073 & 0.022 \\
Federal corporate tax rate & 0.453 & 0.054 \\
Ln(national employment) & 4.688 & 0.079 \\
State personal income growth rate & 0.017 & 0.022 \\
National unemployment rate & 0.069 & 0.012 \\
Share of national manufacturing & 0.023 & 0.023 \\
Ln(manufacturing employment) & 12.432 & 1.095 \\
Ln(total employment) & 14.135 & 0.95 \\
Ln(real manufacturing wage) & 3.33 & 0.161 \\
Number of Observations & 732 & \\
\hline
\end{tabular}

a Payroll weight is the payroll weight in the apportionment formula (e.g., $33 \%, 50 \%, 100 \%$ ).

State payroll burden is (state corporate tax rate - state corporate tax rate $\mathrm{x}$ federal corporate tax rate) $\mathrm{x}$ payroll weight. State corporate tax rate is the top corporate statutory rate imposed by the state.

Federal corporate tax rate is the top corporate statutory rate.

Ln(national employment) is the log of national total employment

State personal income growth rate is the state's growth rate in per capital personal income.

National unemployment rate is the national unemployment rate in percent.

Number of states with payroll $<1 / 3$ is the number of states with payroll weights less than $1 / 3$.

Share of national manufacturing is the state's share of national manufacturing employment.

Ln'total employment) and $\operatorname{Ln}($ manufacturing employment) are the log of total employment and manufacturing employment, respectively. Ln(real manufacturing wage) is the log of the state's real manufacturing wage. 


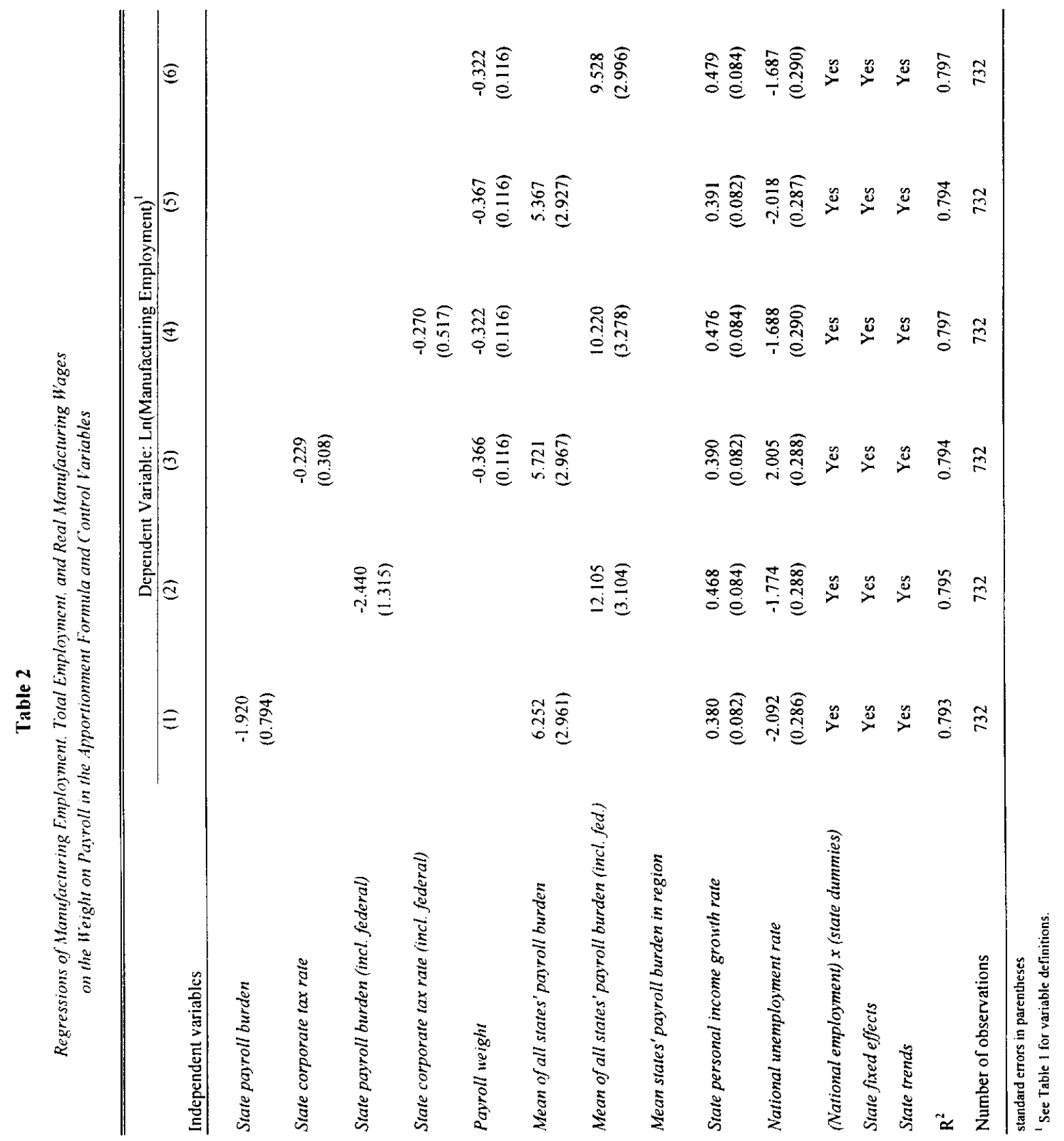




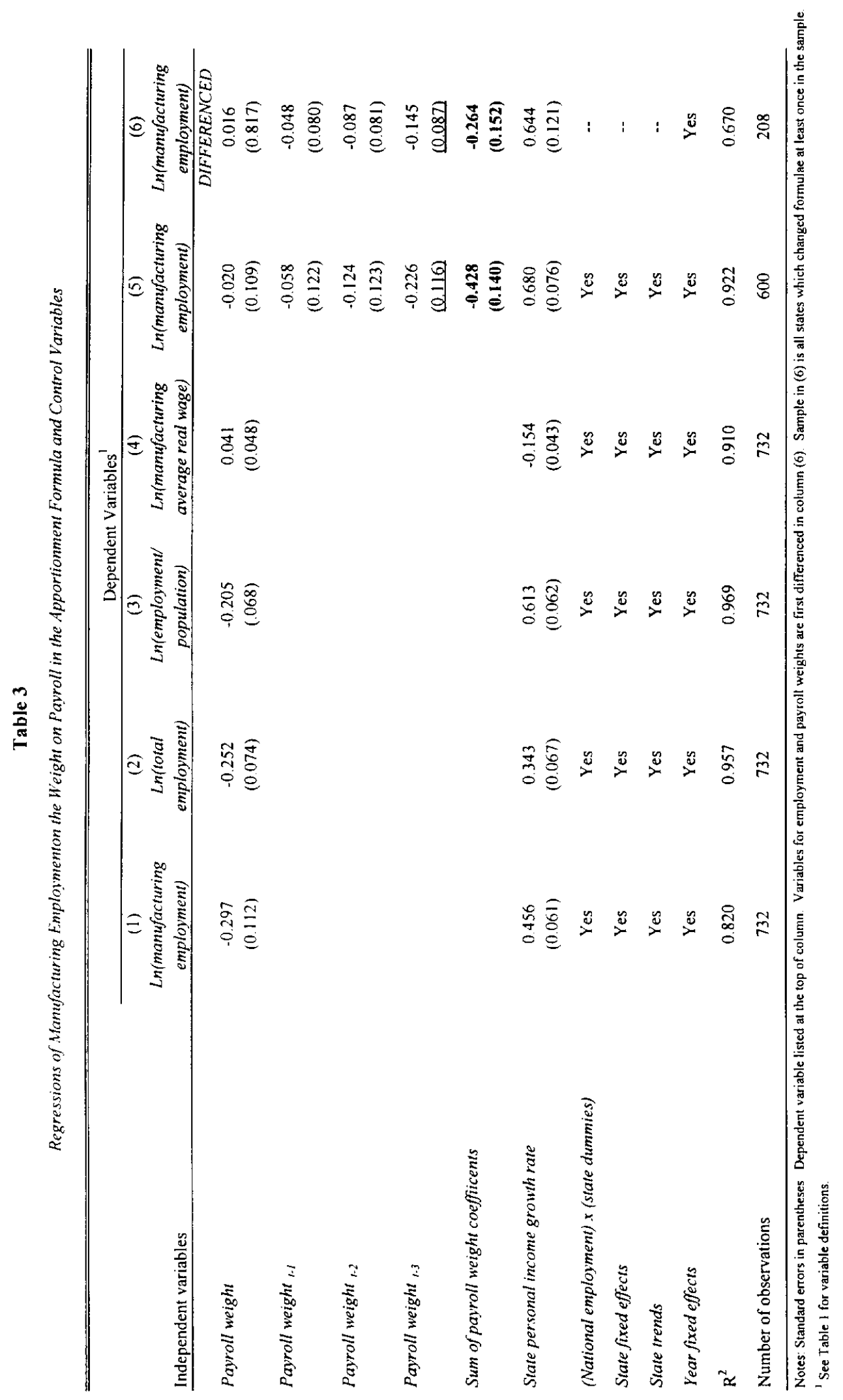

